\title{
Тривожні та депресивні розлади у хворих на системний червоний вовчак
}

\author{
С.О. Макаров \\ Дніпровський державний медичний університет, Дніпро, Україна
}

\begin{abstract}
Анотація. Стаття присвячена вивченню розладів емоційно-вольової сфери, зокрема тривожного та депресивного розладів, у хворих на системний червоний вовчак (СЧВ). Афективні порушення $\epsilon$ одними з найбільш поширених проявів СЧВ, що асоційовані з низкою інших клінічних факторів та суттєво впливають на якість життя хворих. Мета: вивчити поширеність та характеристики депресивних і тривожних симптомів у хворих на СЧВ. Об'єкт і методи дослідження. Об'єктом дослідження були емоційно-вольові порушення, зокрема тривожні та депресивні прояви, у хворих на СЧВ. Оцінку емоційно-вольової сфери проводили за допомогою Госпітальної шкали тривоги та депресії (Hospital Anxiety and Depression Scale - HADS), шкали депресії Бека (Beck Depression Inventory - BDI) та шкали тривожності Спілбергера - Ханіна (State-Trait Anxiety Inventory - STAI). Обробку даних проводили методами параметричної та непараметричної статистики. Результати. Проведено комплексне обстеження 64 хворих на СчВ. Усі хворі пройшли тестування задля оцінки психоемоційного статусу з використанням HADS, BDI, STAI. B усіх пацієнтів групи порівняння визначено нормальний рівень як тривожності, так і депресії, тоді як у основній групі у 63,0\% обстежених діагностували клінічно виражену тривогу (>11 балів за HADS), а у 57,4\% — клінічно виражену депресію. Середній рівень депресії, що визначали за шкалою BDI, становив у хворих основної групи $17,0(9,0 ; 21,0)$ балів, тоді як у пацієнтів групи порівняння - 17,0 $(9,0 ; 21,0) 6$ балів $(p<0,001)$. Між групами дослідження виявлено статистично значущі розбіжності за показниками як особистісної, так і ситуативної тривожності з переважанням показників у основній групі дослідження: $20,0(17,0 ; 24,0)$ балів порівняно 315,5 (14,0; 18,0$)$ бала та $39,0(28,0 ; 52,0)$ балів порівняно з 25,0 $(14,0 ; 29,0)$ балами відповідно $(p<0,01)$. Висновок. Поширеність тривожних і депресивних розладів $\epsilon$ високою у пацієнтів із СЧВ. Своєчасне виявлення та лікування цих проявів повинно бути одним із пріоритетних напрямків роботи ревматологів, неврологів і психіатрів, оскільки ці розлади асоційовані з низкою інших факторів, що також потребують уваги лікарів і значно знижують якість життя пацієнтів.
\end{abstract}

Ключові слова: системний червоний вовчак, тривога, депресія, шкала депресії Бека, Госпітальна шкала тривоги та депресії, опитувальник Спілбергера - Ханіна.

\section{Вступ}

Системний червоний вовчак (СЧВ) - аутоімунне хронічне захворювання, що характеризується мультиорганним ураженням і уражує переважно осіб молодого віку жіночої статі [1-3]. Клінічна картина захворювання являє собою значне розмаїття симптомів та проявів, що мають різні патогенетичні механізми, більшість 3 яких недостатньо з'ясовані.

Ураження центральної та периферичної нервової системи та асоційовані 3 ними неврологічні та нейропсихіатричні прояви традиційно узагальнюють терміном «нейропсихіатричний системний червоний вовчак» (НСЧВ). Американська колегія ревматологів (American College of Rheumatology) включила в цей термін 19 клінічних синдромів [4].

Поширеність нейропсихіатричної симптоматики у пацієнтів із СЧВ коливається в межах 12-95\% [5]. Тривожні та депресивні розлади - одні з найпоширеніших проявів НСЧВ. Встановлено, що їх поширеність серед пацієнтів із СЧВ майже у 2 рази більша, ніж у загальній популяції [6-9]. Поширеність депресивних розладів у пацієнтів із СЧВ коливається в межах 2,1-78,6\%, тривожних розладів - 2,9-84,9\% [10-13].

За численними даними, ці два прояви значно впливають на загальний стан пацієнта та суттєво погіршують якість його життя $[11,14,15]$. Так, встановлено, що тривожність та депресія у пацієнтів із СЧВ пов'язані з такими факторами, як наявність шкірних проявів захворювання [16], підвищена втомлюваність та більш високий рівень болю [17], більш високий ступінь активності хвороби [18-20], нещодавно встановлений діагноз «системний червоний вовчак» [16]. Беручи це до уваги, можна стверджувати, що своєчасне виявлення та лікування цих проявів $\epsilon$ одним із важливих підходів у тактиці ведення таких пацієнтів.

Мета дослідження: вивчити поширеність та характеристики депресивних і тривожних симптомів у хворих на СЧВ.

\section{Об'єкт і методи дослідження}

Об'єктом дослідження були емоційно-вольові порушення, зокрема тривожні та депресивні прояви, у хворих на СЧВ.
Усім хворим проводили поглиблене клініко-неврологічне та нейропсихологічне дослідження. Оцінку емоційно-вольової сфери проводили за допомогою Госпітальної шкали тривоги та депресії (Hospital Anxiety and Depression Scale - HADS), шкали депресії Бека (Beck Depression Inventory - BDI) та шкали тривожності Спілбергера - Ханіна (State-Trait Anxiety Inventory - STAI). Обробку даних проводили методами параметричної та непараметричної статистики.

HADS - широко вживаний простий скринінговий метод виявлення тривожності та депресії, який розроблений A.S. Zigmond та R.P. Snaith у 1983 р. для пацієнтів соматичних стаціонарних відділень [21]. Шкала розділена на 2 частини, які присвячені проявам тривоги та депресії відповідно. Інтерпретація результатів базується на сумарній кількості балів, яку набирає пацієнт за цими двома розділами окремо. Виділяють три параметри значень:

- 0-7 балів - норма;

- 8-10 балів - субклінічно виражена тривога/депресія;

- $\geq 11$ балів - клінічно виражена тривога/депресія.

$\mathrm{BDI}$ - опитувальник, розроблений і запропонований для використання А.Т. Весk та співавторами у 1961 р. [22]. Він містить визначений набір скарг, характеристик та симптомів депресії, що мають найбільш велике значення та які пред'являють пацієнти з депресі$\epsilon ю$ найчастіше. Анкета включає 21 категорію скарг і симптомів, що складається з декількох (4-5) тверджень, які відповідають різним проявам депресії. Залежно від ступеня вираженості симптому кожному твердженню присвоєно значення від 0 до 3. Категорії 1-13 характеризують когнітивно-афективні прояви депресії, категорії 14-21 - соматичні прояви. Інтерпретація результатів базується на загальній сумі балів і має наступні параметри значень:

- 0-9 - відсутність депресії;

- 10-15 - легка депресія;

- 16-19 - помірна депресія;

- 20-29 - виражена депресія;

- 30-63 - тяжка депресія.

STAI - шкала, розроблена C.D. Spielberger та співавторами у 1980 р. для оцінки тривожності [23] та адаптована російською 
мовою ЮЛ. Ханіним (тому на теренах пострадянських країн використовують назву «шкала Спілбергера - Ханіна»). STAI складається з двох частин: шкали особистісної тривожності та шкали ситуативної тривожності. Опитувальник складається з 20 тверджень, що характеризують тривожність як психічну реакцію, та 20 тверджень, що характеризують тривожність як рису особистості. За результатами обстеження виділяють наступні параметри значень:

- <30 балів - низький рівень тривожності;

- 31-45 балів - помірна тривожність;

- $\geq 46$ балів - висока тривожність.

\section{Результати}

Проведено комплексне обстеження 64 хворих на СЧВ, що проходили лікування у відділеннях ревматології та нефрології КП «Дніпропетровська обласна клінічна лікарня ім. І.І. Мечникова» ДОР» протягом 2018-2021 рр., яке включало повне клініконеврологічне обстеження, нейропсихологічне тестування, лабораторне та радіологічне дослідження.

Особи жіночої статі становили більшість обстежених паці$\epsilon$ нтів $(85,9 \%-55$ хворих), частка осіб чоловічої статі становила

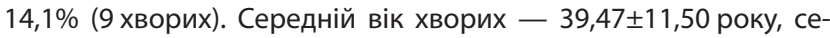
редній вік встановлення діагнозу $-29,75 \pm 9,03$ року.

Неврологічна симптоматика виявлена у 54 (84,38\%) обстежених. Ці пацієнти склали основну групу дослідження (1-ша група). 10 (15,62\%) пацієнтів, у яких не виявлено вищезазначеної симптоматики, увійшли у групу контролю (2-га група).

Усі хворі пройшли тестування задля оцінки психоемоційного статусу з використанням HADS, BDI, STAI.

Опитування показали, що скарги, які зазвичай пред'являють пацієнти для описання тривожного або депресивного стану, були одними з найпоширеніших. Так, скарги на тривожність висловлювали $37(57,8 \%)(45,7 ; 49,9)$, пригніченість настрою - 35 (54,7\%) $(42,5 ; 66,9)$, плаксивість - $20(31,2 \%)(19,9 ; 42,6)$ обстежених. Стомлюваність, яка, за даними деяких авторів, $\epsilon$ проявом, що часто асоційований з тривогою та депресією [17], була найпоширенішою скаргою: її висловлювали 42 (65,6\%) $(54,0 ; 77,2)$ обстежених.

Оцінку рівня тривоги і депресії за шкалою HADS у обстежених хворих на СЧВ наведено у табл. 1.

Між дослідженими групами за тестом HADS виявлено розбіжності $(p<0,001)$ за середнім рівнем як тривоги, так і депресії, із суттєвим переважанням середніх балів в основній групі дослідження (рис. 1).

В усіх обстежених пацієнтів групи порівняння визначено нормальний рівень як тривожності, так і депресії, тоді як в основній групі у 63,0\% обстежених діагностували клінічно ви-

Таблиця 1 Оцінка рівня тривоги і депресії у обстежених хворих на СЧВ за шкалою HADS

\begin{tabular}{|c|c|c|c|c|}
\hline HADS & $\begin{array}{c}\text { Усі } \\
\text { обстежені, } \\
\text { n=64 }\end{array}$ & $\begin{array}{c}\text { 1-ша } \\
\text { rpyna, } \\
\mathrm{n}=54\end{array}$ & $\begin{array}{c}2 \text { 2-га група, } \\
n=10\end{array}$ & $\mathbf{p}$ \\
\hline $\begin{array}{l}\text { Рівень тривоги за HADS } \\
\text { Ме }(25 \% ; 75 \%)\end{array}$ & $\begin{array}{c}12,0(6,0 ; \\
16,0)\end{array}$ & $\begin{array}{l}13,0(7,0 ; \\
17,0)\end{array}$ & $4,5(4,0 ; 6,0)$ & $<0,001$ \\
\hline \multicolumn{5}{|c|}{ Розподіл за рівнем тривоги за HADS, n (\%) } \\
\hline Норма (0-7 балів) & $27(42,2)$ & $17(31,5)$ & $10(100)$ & \multirow{3}{*}{$<0,001^{*}$} \\
\hline Субклінічна тривога (8-10 балів) & $3(4,7)$ & $3(5,6)$ & $0(0)$ & \\
\hline Клінічна тривога (>11 балів) & $34(53,1)$ & $34(63)$ & $0(0)$ & \\
\hline $\begin{array}{l}\text { Рівень депресії за HADS } \\
\text { Мe }(25 \% ; 75 \%)\end{array}$ & $\begin{array}{c}10,0(4,0 ; \\
15,0)\end{array}$ & $\begin{array}{c}12,0(5,0 ; \\
16,0)\end{array}$ & $3,0(2,0 ; 4,0)$ & $<0,001$ \\
\hline \multicolumn{5}{|c|}{ Розподіл за рівнем депресії за HADS, n (\%) } \\
\hline Норма (0-7 балів) & $28(43,8)$ & $18(33,3)$ & $10(100)$ & \multirow{3}{*}{$=0,005^{*}$} \\
\hline Субклінічна депресія (8-10 балів) & $5(7,8)$ & $5(9,3)$ & $0(0)$ & \\
\hline Клінічна депресія (>11 балів) & $31(48,4)$ & $31(57,4)$ & $0(0)$ & \\
\hline $\begin{array}{l}\text { Рівень депресії за BDI } \\
\text { Мe (25\%; } 75 \%)\end{array}$ & $\begin{array}{c}15,5(8,0 ; \\
21,0)\end{array}$ & $\begin{array}{l}17,0(9,0 ; \\
21,0)\end{array}$ & $7,0(4,0 ; 8,0)$ & $<0,001$ \\
\hline
\end{tabular}

p — розбіжності між групами за критерієм критерій Манна — Уітні (U); * розбіжності між розподілом за критерієм х² Пірсона.
Рисунок 1 Оцінка рівня тривоги і депресії у обстежених хворих за шкалою HADS у групах дослідження (середні бали медіана, інтерквартильний розмах та мінімальне і максимальне значення)

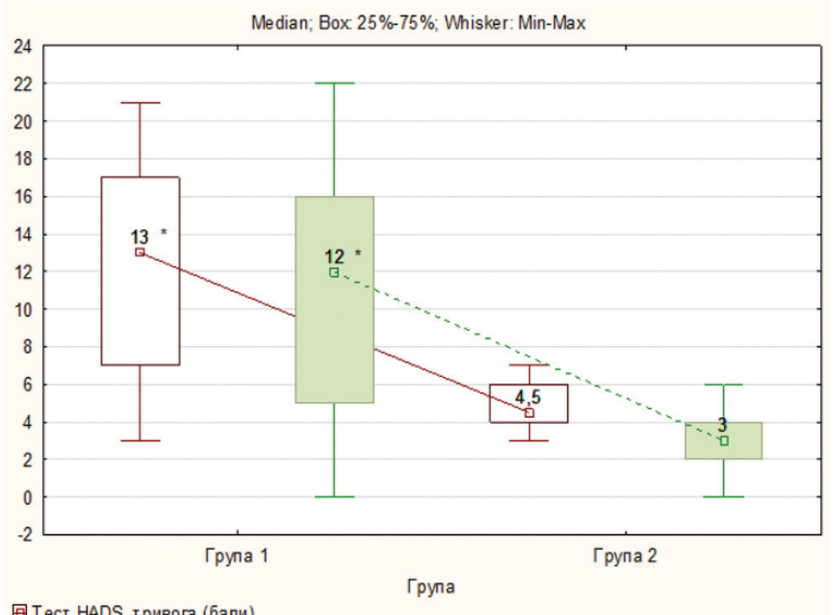

回 Tест HADS, тривога (бали)

Tecr HADS, депресія (бали)

*p<0,001 за критерієм критерій Манна — Уітні (U) порівняно 3 2-ю групою.

Рисунок 2 Розподіл обстежених хворих за рівнем тривоги і депресії за шкалою HADS у групах дослідження (\%)

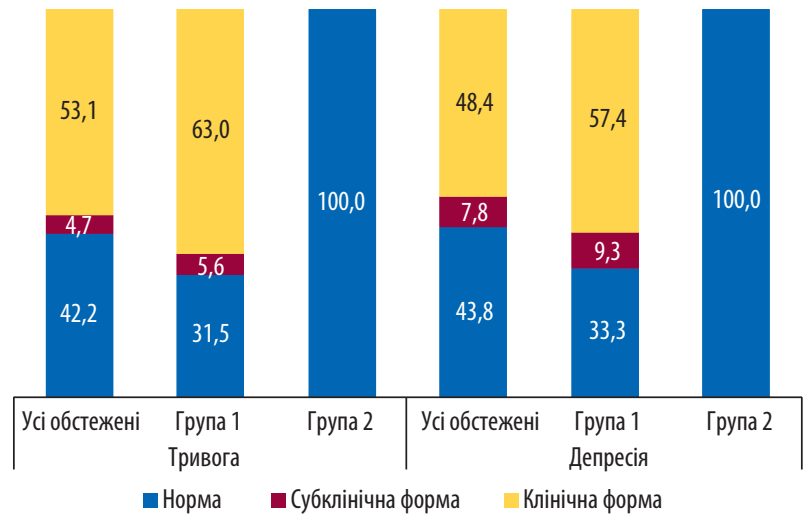

ражену тривогу (>11 балів за HADS), а у 57,4\% - клінічно виражену депресію (рис. 2).

Середній рівень депресії, яку визначали за шкалою BDI, становив у хворих основної групи $17,0(9,0 ; 21,0)$ балів, тоді як у паці$\epsilon$ тів групи порівняння - $17,0(9,0 ; 21,0)$ балів $(p<0,001)$.

Як і за шкалою HADS, так і за шкалою BDI, у хворих 2-ї групи не визначали депресивного стану, тоді як у хворих 1-ї групи за шкалою BDI у 24,1\% виявлено помірну, у 33,3\% - виражену та у 1 хворого - тяжку депресію. Лише у $1 \frac{1}{3}$ хворих основної групи (31,5\%) була відсутня депресивна симптоматика (табл. 2).

Оцінка рівня тривожності показала (табл. 3, рис. 3), що у більшості пацієнтів $(92,2 \%)$ рівень особистісної тривожності був низьким (<30 балів) і в середньому становив $19,5(16,0 ; 23,0)$ балів. Показники реактивної тривожності у більшості випадків були низькими (37,5\%) або помірними (31,3\%), в середньому становили 37,5 (27,0; $51,0)$ бала. Зазначимо, що рівень ситуативної тривожності перевищував рівень особистісної тривожності у групах дослідження та в цілому серед усіх обстежених ( $<<0,01$ за Т-критерієм Вілкоксона).

Між групами дослідження виявлено статистично значущі розбіжності за показниками як особистісної, так і ситуативної тривожності із переважанням показників у основній групі дослідження: $20,0(17,0 ; 24,0)$ балів порівняно $315,5(14,0 ; 18,0)$ бала та $39,0(28,0 ;$ $52,0)$ балів порівняно з 25,0 $(14,0 ; 29,0)$ балами відповідно ( $<<0,01)$.

У хворих 1-ї групи визначали переважно помірний $(35,2 \%)$ та високий $(37,0 \%)$ рівні реактивної тривожності, тоді як у 2-й низький $(90,0 \%)$ зі статистично значущими розбіжностями між групами $(p=0,001)$. 
Таблиця 2 Оцінка рівня депресії у обстежених хворих на СЧВ за BDI

\begin{tabular}{|c|c|c|c|c|}
\hline BDI & $\begin{array}{c}\text { Усі } \\
\text { обстежені, } \\
\text { n=64 }\end{array}$ & $\begin{array}{c}\text { 1-ша } \\
\text { група, } \\
\text { n=54 }\end{array}$ & $\begin{array}{c}\text { 2-га група, } \\
n=10\end{array}$ & $\mathbf{p}$ \\
\hline $\begin{array}{l}\text { Рівень депресії за BDI } \\
\text { Ме }(25 \% ; 75 \%)\end{array}$ & $\begin{array}{l}15,5(8,0 ; \\
21,0)\end{array}$ & $\begin{array}{c}17,0(9,0 ; \\
21,0)\end{array}$ & $7,0(4,0 ; 8,0)$ & $<0,001$ \\
\hline \multicolumn{5}{|c|}{ Розподіл за рівнем депресії за BDI, n (\%) } \\
\hline Депресія відсутня (0-9 балів) & $27(42,2)$ & $17(31,5)$ & $10(100)$ & \multirow{5}{*}{$=0,003^{*}$} \\
\hline $\begin{array}{l}\text { Легка («субклінічна») депресія } \\
\text { (10-15 балів) }\end{array}$ & $5(7,8)$ & $5(9,3)$ & $0(0)$ & \\
\hline Помірна депресія (16-19 балів) & $13(20,3)$ & $13(24,1)$ & $0(0)$ & \\
\hline $\begin{array}{l}\text { Середньої тяжкості (виражена) депресія } \\
\text { (20-29 балів) }\end{array}$ & $18(28,1)$ & $18(33,3)$ & $0(0)$ & \\
\hline Тяжка депресія ( $\geq 30$ балів) & $1(1,6)$ & $1(1,9)$ & $0(0)$ & \\
\hline
\end{tabular}

p — розбіжності між групами за критерієм критерій Манна — Уітні (U); * розподілом за критерієм $\chi^{2}$ Пірсона.

Таблиця 3 Оцінка рівня реактивної (ситуативної) та особистісної тривожності у хворих на СЧВ за STAI

\begin{tabular}{|c|c|c|c|c|}
\hline STAI & $\begin{array}{c}\text { Усі } \\
\text { обстежені, } \\
\text { n=64 }\end{array}$ & $\begin{array}{c}1 \text { 1-ша } \\
\text { група, } \\
\mathrm{n}=54\end{array}$ & $\begin{array}{c}\text { 2-га група, } \\
n=10\end{array}$ & $\mathbf{p}$ \\
\hline $\begin{array}{l}\text { Реактивна тривожність } \\
\text { Ме }(25 \% ; 75 \%)\end{array}$ & $\begin{array}{c}37,5(27,0 \\
51,0)\end{array}$ & $\begin{array}{c}39,0(28,0 ; \\
52,0)\end{array}$ & $\begin{array}{c}25,0(14,0 \\
29,0)\end{array}$ & $<0,001$ \\
\hline
\end{tabular}

\begin{tabular}{|c|c|c|c|c|}
\hline \multicolumn{5}{|c|}{ Розподіл за вираженістю рівня реактивної тривожності, n (\%) } \\
\hline Низький (<30 балів) & $24(37,5)$ & $15(27,8)$ & $9(90,0)$ & \\
\hline Помірний (31-44 бали) & $20(31,3)$ & $19(35,2)$ & $1(10,0)$ & $=0,001^{*}$ \\
\hline Високий ( $\geq 45$ балів) & $20(31,3)$ & $20(37,0)$ & $0(0)$ & \\
\hline $\begin{array}{l}\text { Особистісна тривожність } \\
\text { Ме }(25 \% ; 75 \%)\end{array}$ & $\begin{array}{c}19,5(16,0 ; \\
23,0)\end{array}$ & $\begin{array}{c}20,0(17,0 \\
24,0)\end{array}$ & $\begin{array}{c}15,5(14,0 \\
18,0)\end{array}$ & $=0,003$ \\
\hline
\end{tabular}

Me $(25 \% ; 75 \%)$

Розподіл за вираженістю рівня особистісної тривожності, $\mathrm{n}(\%)$

\begin{tabular}{lccc}
\hline Низький (<30 балів) & $59(92,2)$ & $49(90,7)$ & $10(100,0)$ \\
\cline { 1 - 4 } Помірний $(31-44$ бали) & $2(3,1)$ & $2(3,7)$ & $0(0)$ \\
\cline { 1 - 2 } Високий $(\geq 45$ балів) & $3(4,7)$ & $3(5,6)$ & $0,605^{*}$
\end{tabular}

p — розбіжності між групами за критерієм критерій Манна — Уітні (U); * розбіжності між розподілом за критерієм $x^{2}$ Пірсона.

Рисунок 3 Середні бали реактивної (ситуативної) та особистісної тривожності у хворих на СЧВ за шкалою STAI за групами дослідження (медіана та інтерквартильний розмах)

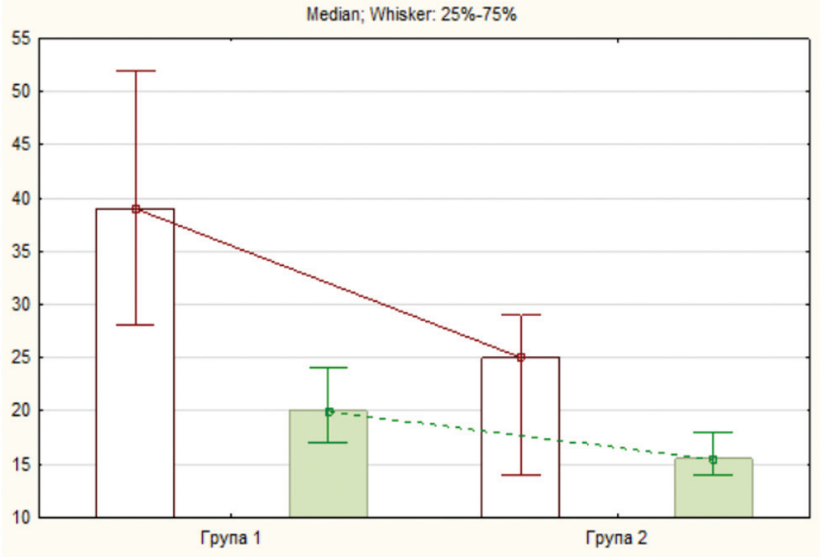

Гpyna

回 STAI реактивна тривожніст ь, бали

STAI особистісна тривожність, бали

У розподілі за вираженістю рівня особистісної тривожності розбіжностей між групами не виявлено ( $>00,05)$, у обстежених обох груп визначали переважно низький рівень тривожності.

Результати обстеження за вищенаведеними тестами корелюють між собою сильними та середньої сили зв'язками. Найпотужніші зв'язки виявлено між показниками депресії за шкалою BDI та депресією за шкалою HADS $\left(r_{s}=0,95 ; p<0,001\right)$, між депресією та тривогою за шкалою HADS $\left(r_{s}=0,86 ; p<0,001\right)$, між тривогою за шкалою HADS та депресією за шкалою BDI $\left(r_{s}=0,87 ; p<0,001\right)$.

\section{Обговорення}

Тривожні та депресивні розлади - одні з найпоширеніших клінічних проявів НСЧВ.

Нейропсихологічне обстеження з використанням HADS i BDI показало високу поширеність клінічно вираженої тривоги та депресії як серед загальної кількості, так і серед пацієнтів із НСЧВ (1-ша група), тоді як серед пацієнтів 2-ї групи ці прояви не відмічалися. Ці результати корелюють з даними інших досліджень, проте зазначимо, що отримані нами дані дещо перевищують зазначені в літературі [8].

Результати обстеження за STAI показали загалом в обох групах низький рівень особистісної тривожності та високий рівень ситуативної тривожності (зі статистично значущим переважанням показників у 1-й групі).

\section{Висновок}

Поширеність тривожних і депресивних розладів $\epsilon$ високою у пацієнтів із СЧВ. Своєчасне виявлення та лікування цих проявів повинно бути одним із пріоритетних напрямків роботи ревматологів, неврологів і психіатрів, оскільки ці розлади асоційовані з низкою інших факторів, що також потребують уваги лікарів і значно знижують якість життя пацієнтів.

\section{Конфлікт інтересів}

Конфлікту інтересів немає.

\section{Назва та номер державної реєстрації наукової теми}

Робота $\epsilon$ фрагментом виконання теми науково-дослідної роботи кафедри неврології державного закладу «Дніпропетровська медична академія МОЗ України» «Порушення нервової системи при пароксизмальних, нейроімунологічних та цереброваскулярних захворюваннях», № державної реєстрації 0119 U000001.

Робота виконана в рамках дисертаційної роботи «Особливості порушень нервової системи та їх автоімунні маркери у хворих на системний червоний вовчак».

\section{Список використаної літератури}

1. Makarov S.0. (2018) Nervous system impairment under systemic lupus erythematosus: pathogenesis aspects, prevalence and views on clinical manifestations classification. Ukr. Neurol. J., 2: 25-29.

2. González L.A., Ugarte-Gil M.F., Alarcón G.S. (2021) Systemic lupus erythematosus: The search for the ideal biomarker. Lupus, 30(2): 181-203.

3. Makarov S.0. (2021) Structure of neurological manifestations in patients with systemic lupus erythematosus. Bull. Probl. Biol. Med., 159(2): 90-93.

4. Liang M.H.,Corzillius M., BaeS.C. etal (1999) The American College ofRheumatologynomenclature and case definitions for neuropsychiatric lupus syndromes. Arthritis rheum., 42(4): 599-608.

5. Jeltsch-David H., Muller S. (2014) Neuropsychiatric systemic lupus erythematosus: pathogenesis and biomarkers. Nat. Rev. Neurol., 10(10): 579-596.

6. Kheirandish M., Faezi S.T., Paragomi P. et al. (2015) Prevalence and severity of depression and anxiety in patients with systemic lupus erythematosus: An epidemiologic study in Iranian patients. Mod. Rheumatol., 25(3): 405-409.

7. Moustafa A.T., Moazzami M., Engel L. et al. (2020) Prevalence and metric of depression and anxiety in systemic lupus erythematosus: a systematic review and meta-analysis. In Semin Arthritis Rheum., 50(1): 84-94.

8. Zhang L., Fu T., Yin R., Zhang Q., Shen B. (2017) Prevalence of depression and anxiety in systemic lupus erythematosus: a systematic review and meta-analysis. BMC psychiatry, 17(1):1-14.

9. Bachen E.A., Chesney M.A., Criswell L.A. (2009) Prevalence of mood and anxiety disorders in women with systemic lupus erythematosus. Arthritis Rheum., 61(6): 822-829.

10. SeawelL A.H., Danoff-Burg S. (2005) Body image and sexuality in women with and without systemic lupus erythematosus. Sex Roles, 53(11): 865-876.

11. Hanly J.G., Su L., Urowitz M.B. et al (2015) Mood disorders in systemic lupus erythematosus: results from an international inception cohort study. Arthritis Rheumatol., 67(7): 1837-1847.

12. Brey R.L., Holliday S.L., Saklad A.R. et al. (2002) Neuropsychiatric syndromes in lupus: prevalence using standardized definitions. Neurology, 58(8): 1214-1220.

13. Yilmaz-Oner S., Oner C., Dogukan F.M. et al. (2015) Anxiety and depression predict quality of life in Turkish patients with systemic lupus erythematosus. Clin. Exp. Rheumatol., 33(3):360-365. 
14. Ainiala H., Loukkola J., Peltola J. et al. (2001) The prevalence of neuropsychiatric syndromes in systemic lupus erythematosus. Neurology, 57(3): 496-500.

15. Tisseverasinghe A., Peschken C., Hitchon C. (2018) Anxiety and mood disorders in systemic lupus erythematosus: current insights and future directions. Curr. Rheumatol. Rep., 20(12): $1-11$.

16. Huang X., Magder L.S., Petri M. (2014) Predictors of incident depression in systemic lupus erythematosus. J. Rheumatol., 41(9): 1823-1833.

17. Figueiredo-Braga M., Cornaby C., Cortez A. et al. (2018) Depression and anxiety in systemic lupus erythematosus: the crosstalk between immunological, clinical, and psychosocial factors. Medicine, 97(28).

18. McCormick N., Trupin L., Yelin E.H., Katz P.P. (2018) Socioeconomic predictors of incident depression in systemic lupus erythematosus. Arthritis Care Res., 70(1): 104-113.

19. Uguz F., Kucuk A., Cicek E. et al. (2013) Mood, anxiety and personality disorders in patients with systemic lupus erythematosus. Compr. Psychiatry, 54(4): 341-345.

20. Tay S.H., Cheung P.P.M., Mak A. (2015) Active disease is independently associated with more severe anxiety rather than depressive symptoms in patients with systemic lupus erythematosus. Lupus, 24(13): 1392-1399.

21. Zigmond A.S., Snaith R.P. (1983) The hospital anxiety and depression scale. Acta Psychiatr. Scand., 67(6): 361-370. doi: 10.1111/j.1600-0447.1983.tb09716.x.

22. Beck..T., Ward C.H., Mendelson M. et al. (1961) An inventory for measuring depression. Arch. Gen. Psychiatry, 4(6): 561-571.

23. Spielberger C.D., Vagg P.R., Barker L.R. et al. (1980) The factor structure of the state-trait anxiety inventory. Stress and anxiety, 7: 95-109.

\section{Anxiety and depressive disorders in patients with systemic lupus erythematosus}

\section{S.O. Makarov}

Dnipro State Medical University, Dnipro, Ukraine

Abstract. The article is devoted to the study of disorders of the emotional-volitional sphere, in particular, anxiety and depressive

Відомості про автора:
Макаров Сергій Олександрович — асистент кафедри неврології Дніпровського державно-
го медичного університету, Дніпро, Україна.
Адреса для кореспонденції:
Макаров Сергій Олександрович
49044, Дніпро, вул. Володимира Вернадського, 9
E-mail: makarov295062@gmail.com

disorders, in patients with systemic lupus erythematosus (SLE). Affective disorders are one of the most common manifestations of SLE, which are associated with a number of other clinical factors and have a significant impact on the quality of life of patients. Aim: to study the prevalence and characteristics of depressive and anxiety symptoms in SLE patients. Object and research methods. The object of the research was emotional disorders, in particular, anxious and depressive manifestations of SLE patients. The emotional-volitional sphere was assessed using the hospital anxiety and depression scale (HADS), the Beck depression scale (BDI), and the State-Trait Anxiety Inventory (STAI). Data processing was carried out by methods of parametric and nonparametric statistics. Results. An advanced examination of 64 patients was performed. All patients in the comparison group had a normal level of both anxiety and depression, while in the main group, $63.0 \%$ of the examined patients were diagnosed with clinically severe anxiety (>11 points according to HADS), and $57.4 \%$ had clinically severe depression. The average level of depression, as determined by the $\mathrm{BDI}$, was $17.0(9.0 ; 21.0)$ points in the patients of the main group, while in the comparison group it was $17.0(9.0 ; 21.0)$ points $(p<0.001)$. Between the study groups, statistically significant discrepancies were revealed in terms of both personal and situational anxiety with a predominance of indicators in the main study group: $20.0(17.0 ; 24.0)$ points compared to $15.5(14.0 ; 18,0)$ points and $39.0(28.0 ; 52.0)$ points compared to 25.0 (14.0; 29.0) points, respectively $(p<0.01)$. Conclusions. The prevalence of anxiety and depressive disorders is high in patients with SLE. Timely identification and treatment of these manifestations should be one of the priority areas of work for rheumatologists, neurologists and psychiatrists, since these disorders are associated with a number of other factors that also require the attention of doctors and significantly reduce the quality of life of patients.

Key words: systemic lupus erythematosus, anxiety, depression, Beck Depression Inventory, Hospital Anxiety and Depression Scale, StateTrait Anxiety Inventory.

\section{Information about the author:}

Makarov Serhii 0. - Assistant Professor of Department of Neurology of the Dnipro State Medical University, Dnipro, Ukraine.

\section{Address for correspondence:}

Serhii Makarov

49044, Dnipro, Volodymyr Vernadsky str., 9

E-mail: makarov295062@gmail.com 